\title{
Comparative analysis of relevant climate change, landscape and regional development strategies regarding the areas pertaining to Debrecen (Hajdú-Bihar County)
}

\author{
Krisztina BÁNÓCZKI, ${ }^{1}$ Péter CSORBA ${ }^{2}$ \\ ${ }^{1}$ Department of Landscape Protection and Environmental Geography, University of Debrecen, \\ Debrecen, Hungary, e-mail: banoczki.krisztina@science.unideb.hu \\ ${ }^{2}$ Department of Landscape Protection and Environmental Geography, University of Debrecen, \\ Debrecen, Hungary, e-mail: csorba.peter@science.unideb.hu
}

Manuscript received: 01 October 2019; revised: 13 November 2019, accepted: 01 December 2019

\begin{abstract}
Today, the countries of the world have to face several global challenges with regard to the plans they have developed together. The protection of the natural values of our country and their sustainable use is receiving more and more attention in today's society. In order to achieve the above, a change of perspective in social strategy built on knowledge and professional training is inevitable. An environmental strategy paradigm shift emphasizing the protection of biodiversity, resources, and landscape cultivation is also necessary. The need for documents providing a basis for the paradigm shift is indubitable; however, more efforts are needed to induce fundamental changes by plans detailed in the documents.

The aim of this study is to review the current environmental protection initiatives in Hajdú-Bihar County and to assess the degree to which the relevant plans are harmonized and that the objectives outlined in the documents overlap.
\end{abstract}

Keywords: climate change, strategy, biodiversity, sustainable development

\section{Introduction}

Developed countries enjoy the benefits of globalization on a daily basis; however, they are less effective in terms of the measures taken to combat its negative consequences. Nevertheless, it is undeniable that the unsustainable use of resources, the increase of biological diversity, and climate change lead to irreversible changes affecting even our everyday lives. According to Climate Change 2014: Synthesis Report, one of the major causes of climate change is the anthropogenic emission of greenhouse gases (burning of fossil fuels and 
industrial processes). This leads to the increase of surface-level mean temperature, the acidification of oceans, the change of global water cycles, the faster melting of ice caps, and the increase of global sea level [4]. Several reports and research studies agree that in order to adapt to the above issues and slow down these processes international cooperation and sustainable economy should be achieved. An economy is considered sustainable when it does use its natural resources but only to a degree that does not have excessive impacts on the carrying capacity and tolerability of the environment [3]. The United Nations Conference on Environment and Development (UNCED) held in Rio de Janeiro in 1992 made the first steps towards this goal, yielding the documents which provide the foundations for today's climate change negotiations. These are the United Nations Framework Convention on Climate Change, the Convention on Biological Diversity (CBD), and the Rio Declaration [5]. This is complemented by the Kyoto Protocol signed in 1997 and effective as of 2005 [6]. Among further climate protection events, the following are also worth mentioning: The World Summit on Sustainable Development (WSSD), which summarized the results achieved during the last ten years passed since UNCED [7]; 10 years later, in 2012, a global summit was held again in Rio de Janeiro: The United Nations Conference on Sustainable Development (UNCSD) [8]. In all three conferences as well as in the preparatory negotiations organized during the interim periods, the representatives of the participant countries agreed that the mitigation of factors causing global climate change is necessary, especially in the form of common obligations. From the above, notable goals are the decrease of greenhouse gases and the compilation of national strategies. In the period between 1992 and 2012 as well as afterwards, the decrease of greenhouse gases was a highlighted issue in almost every conference [9]. However, the participant countries were still not able to complete the objectives determined 27 years ago. The measures regarding the compilation of national strategies are still in development today. For the most part, these strategies serve surveying purposes, and they are rarely implemented successfully. Therefore, despite the many strategies, concrete results reflecting a proactive approach are hard to find. Even though the protection and sustainable use of the natural values of Hungary is becoming more and more important for our society, the contradictions between the basic documents fostering the change in perspective suggest that the presentation of the baseline situation is not the same either at the national or at the local level; priorities and objectives are constantly changing, and there are differences in the methods and tools used for the implementation. 


\section{Materials and methods}

In our study, we attempt to highlight the contradictions found in the following Hungarian strategic documents and development programmes as well as to review the implementation of national objectives in the urban development plans of Hajdú-Bihar County and Debrecen [10-16]:

- National Development 2020 (NF2020),

- National Development 2030 - National Development and Regional Development Plan (NF2030),

- National Climate Change Strategy (NÉS 2008-2025),

- Second National Climate Change Strategy 2014-2025 (NÉS II),

- National Landscape Strategy (NTS),

- Hajdú-Bihar County Regional Development Programme 2014-2020,

- Debrecen MJV Urban Development Concept and Integrated Urban Development Strategy 2014-2020.

\section{Results and discussions}

\section{A. Demographic processes}

One of the main causes of the global issues is the rapid increase of population; however, in Hungary, the population is decreasing and the fundamental problem is emigration. One of the top priorities of the National Development 2020 (NF2020) [10] is to arrest and reverse the negative demographic processes. However, this objective is missing from the National Development 2030 [11] as if it acknowledged the fact that the population of the country is decreasing at a constant rate. The population of Hajdú-Bihar County has been decreasing by approximately 1,000 inhabitants annually since the turn of the millennium - today, the number of inhabitants of the county is close to that of the year 1975. The population of Debrecen had been increasing until 2011, when it reached 210,000; since then, it has been slowly decreasing, and it was only 202,000 in 2017 (KSH) [17].

The constant and even permanent draining effect of the capital, of the western regions and western countries can be detected across the county. According to the National Landscape Strategy (NTS) [14], internal migration affects mainly young career entrants, which leads to the aging of the population in the areas impacted by the emigration processes. Hajdú-Bihar County is not one of the most rapidly aging counties, showing a trend which is even below the national average; e.g. the number of people older than the age of 65 per 100 children is increasing at only a moderate rate according to the data of the Hungarian Central Statistics Office regarding 2009 [17]. 


\section{B. The urban development plan of Debrecen}

The settlement and regional structure of Hungary started to change, as a result of which cities play a more significant role, including Debrecen as a major city in the Great Hungarian Plain since it is one of the most economically developed settlements of the so-called outer city ring (Miskolc-NyíregyházaDebrecen-Békéscsaba-Szeged-Pécs-Kaposvár-Nagykanizsa-ZalaegerszegSzombathely-Sopron-Györ) (according to NF2020). Even though it is a regional centre, it cannot counteract the dominant effect of the capital. However, the city is responsible for providing opportunities for innovation and transmitting development to other Hungarian cities and regions across the border.

Debrecen is a settlement of great economic potential - it is an economic and technological core area because it can build upon more take-off points such as food industry, biomass utilization industries, chemical engineering, or the pharmaceutical industry. The developments made in the field of chemical industry provide more economic advantages. Their regional distribution is focused since they are associated with universities and research centres; therefore, Debrecen has a major advantage in this regard as well. The development of environmental technologies could also provide significant potential for the city. In the MJV Urban Development Concept of Debrecen, we can find more horizontal principles: According to the principle of "Liveable, sustainable housing and institutional environment for the citizens of Debrecen", the key areas of sustainability are the brown-field and green-field investments, building rehabilitation projects, and the touristic use of thermal water. According to the principle of "Improving life quality as a response to the challenges of the aging society", it is necessary to provide healthcare prevention, retirement insurance opportunities and to increase the available recreation services. Furthermore, the principle "Integration of innovation perspective into the economic, societal, and environmental processes" highlights the significant role of innovation and knowledge; therefore, the use of environmentally-friendly technologies can be a key element to the development of this area [16]. The parts of NF2020 and 2030, where the needs and responsibilities of the counties and the capital are discussed, match entirely, and the contents of other sections of the strategies are in accordance as well. However, the green-field industry development approach mentioned in the MJV Urban Development Concept of Debrecen is no more included in NF2030. This is directly contradicted by the statement made in the summer of 2018, according to which the new green-field investment of BMW will be implemented in Debrecen, which can be accompanied with the establishment of a new freeway junction and a new railway section. 


\section{Opportunities for restructuring energy production}

Development strategies include the improvement of environmental quality by focusing on renewable energy sources and the implementation of developments in a way that takes landscape protection aspects into account. Natural resources are becoming scarcer and scarcer and more vulnerable, while the energy demands of Europe continue to increase. That is the reason why the most necessary measures to be taken will increase the degree of energy conservation and energy efficiency by relying more heavily on renewable energy sources. The reform of the Common Agricultural Policy of the EU is partly about achieving a sustainable management of natural resources. Even though the geothermic properties of Hungary are exceptional even on the international level (the Tiszántúl region is one the areas where sun, wind, and geothermic energy use are recommended), their degree of utilization is far from what could be achieved from a technological standpoint. It should be noted that, contrary to the information stated in NF2020, the average wind speed of the region is even lower than the already limited national wind energy potential. In Debrecen and the neighbouring settlements as well as throughout the country, the degree of solar energy utilization is increasing (e.g. with the use of solar cells), but Hungary is still extremely dependent on the import of solar energy carriers. According to the Hajdú-Bihar County Urban Development Programme (2014-2020), the energy efficiency and the ratio of renewable energy should be increased by $20 \%$ and the emission of greenhouse gases should be decreased with $20 \%$ until 2020 to meet the objectives outlined in the EU2020 strategy. According to the programme, the dependence of Hungary on energy import could be reduced to zero with sustainable energy use, the establishment of zero-energy buildings, and the use of energy plants [15]. This dependency is highlighted by the First National Climate Change Strategy (NÉS), according to which approximately $80 \%$ of the domestic energy use is based on fossil fuels, and it is almost entirely imported energy [12]. The increase of energy demands covered through import energy is an important challenge according to NF2020 as well as NF2030. Based on the above, the most important objectives include the increase of energy efficiency and the increase of the ratio of renewable sources. Even though during the 1990s the energy use and output significantly decreased as a consequence of the structural change occurred in the energy sector, no major changes can be expected on the midterm according to NÉS, whereas the goal would be the prevention of industrial developments with large energy demands and greenhouse gas emission. With regard to renewable energy use, in 2001, Hungary committed to double the ratio of renewable energy by 2010 (in 2010, the ratio of renewable energy sources was $8.7 \%$ in the domestic energy supply). Even though the country met this objective in 2005 , it was done mostly by burning forests, which cannot be 
considered a long-term solution. Efforts to achieve these goals go beyond national borders. In terms of the energy efficiency, especially the use of biogas has been the focus of many research programmes (I. Fazekas et al. 2013, Gy. Szabó et al. 2014, Gy. Szabó et al. 2014) within the framework of the cooperation programme between Hungary and Romania [23, 24, 25]. Based on a decision associated with the European Commission, a "renewable heat" directive had to be drawn up, which stated that a support system should be developed for providing the foundations for renewable heating and cooling. In January 2017, METÁR was launched, which is a type of support system for power stations to generate electricity from renewable energy sources [18]. According to NÉS, it is an EU requirement to increase the proportion of biofuel use by $10 \%$. This ratio objective can be met by 2020 through domestic production. It is surprising that these requirements and obligations are not included in any of the national development concepts. The reason for this may be that the national energy policy is committed to increase the capacity of the Paks nuclear plant.

\section{Agriculture as a key sector}

Considering that the county is situated in the Great Hungarian Plain, the most highlighted field in strategies regarding Hajdú-Bihar County was agriculture. Since this sector showed the greatest GDP increase, the area may have significant economic potential. However, the degree of development is unclear - according to National Development 2020, the added value of the sector increased by $10 \%$ in 2011, whereas the same value is $24 \%$ in National Development 2030. With the development of irrigation and using breeds that are better suited to tolerate extreme weather conditions, it should be a sector which not only increases the economic power of the country but adapts to the climate change - at least according to the development plan. However, it raises the question of how sustainable the development of irrigation is if the climatic water balance of the Great Hungarian Plains is already negative. The connection between climate change and the changes occurring in the agricultural sector was already included in the first NÉS. It states that agriculture is especially vulnerable to extreme weather changes. Extreme water balance conditions (drought, floods, and inland water) pose significant economic risks. According to the strategy, agriculture could be the most vulnerable sector to climate change if the land use type is not chosen in accordance with the conditions of the land. According to the second NÉS, the main problem is that the average annual precipitation would decrease, and the amount of precipitation would be redistributed - during winter and summer months, significantly more and less precipitation can be expected respectively. Nevertheless, heavy storms will be more frequent, thereby increasing the risk of floods, and Hungarian rivers may dry to half of their regular 
levels during summer seasons within decades. Furthermore, according to the report, the level of groundwater can also decrease due to lack of supply and the presence of surface water [13].

According to the Hajdú-Bihar County Regional Development Programme, the county is poor in surface water and rich in underground water. From the perspective of climate change, the county is especially vulnerable, and the ratio of regions exposed to the risk of drought is continuously increasing. The most significant issues are the management of rainwater in the areas of settlements, the elimination of inland water from lands, the establishment of irrigation systems, the provision of healthy drinking water, and the diversion and management of communal sewage water. According to the programme, the area of lands which can be irrigated has increased by $55 \%$ since 2000 . The solution could be the complex water management that would include agricultural irrigation, inland water elimination, and storage as well as its use for recreational purposes. With regard to the above, it was almost two decades ago that the CIVAQUA programme was developed, which would transport water from River Tisza to the area of Debrecen via the Eastern Main Canal. The CIVAQUA programme would provide the appropriate water supply for the Tócó stream, solving the problem of managing the water supply of the Erdöspuszta lakes and the capacity expansion of the reservoir of Látókép. However, the elements of the CIVAQUA development programme conceived in the early 2000 s are yet to be realized. These are planned to be completed via a new project (a multi-purpose water management system of Hajdúhátság). The goal is to develop the irrigation potential of the agricultural areas situated west of Debrecen, for which the Eastern Main Canal would provide the water supply. Another goal is to establish the reservoir of the Valley of Ágod as a solution for the inland water diversion and retention issues of the area. The project is aimed to be completed in 2019 [19].

Agricultural professions have a low prestige; therefore, it is advisable to prevent the shortage of professionals in demand in accordance with the objectives determined for the sector. This is further aided by the noteworthy attempt of the University of Debrecen to offer the first agricultural and water management engineer MSc training programme of the country from 2018. The curriculum includes modules of traditional and precision irrigation technologies, water management and quality assurance tasks, the management of oxbow lakes and wetland conservation, and the students will also learn the necessary skills to perform tasks related to hydrology, hydraulics, geoinformatics, remote sensing, and data collection and modelling [20]. 


\section{Vulnerability}

The effects of climate change show a great variability in Hungary - the degree of vulnerability varies from area to area. According to the first NÉS, the entire Carpathian Basin can be considered a vulnerable area. The second NÉS, however, differentiates between the climate change vulnerability of agricultural plant cultivation, forest management, and natural habitats, but neither of these correspond with the figure included in the NF2020 and NF2030 concepts (Fig. 1).

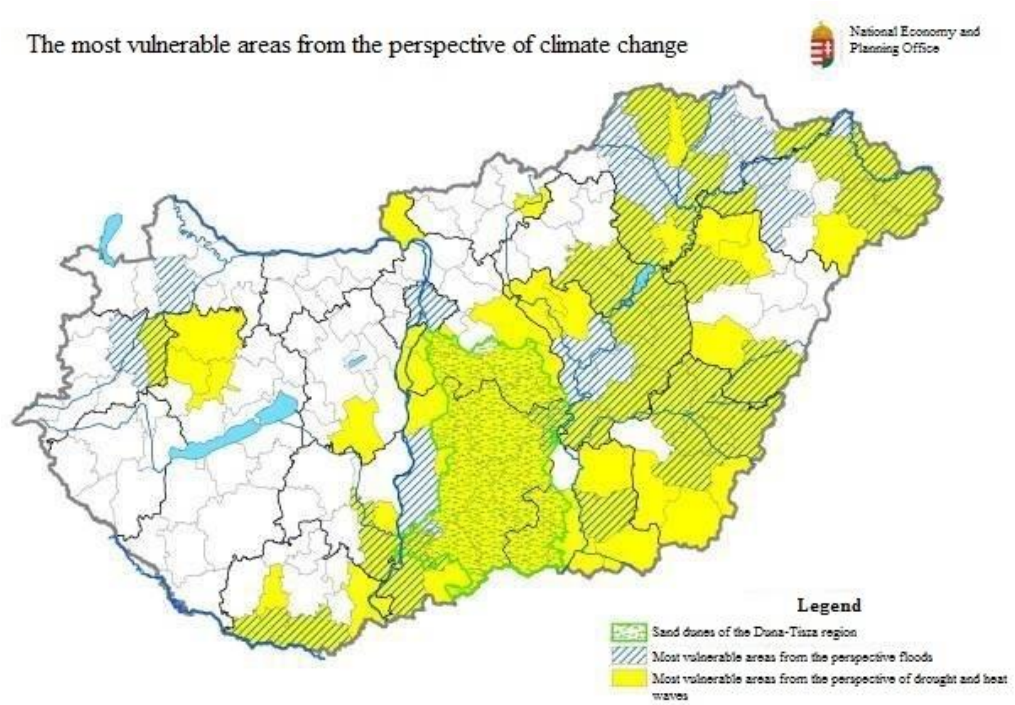

Source: National Development 2020 [10]

Figure 1. The most vulnerable areas from the perspective of climate change

It is problematic that the above figure rates climate vulnerability based on administrative borders and regions, but an essentially natural geographical issue cannot be presented in the framework of administrative units. For example, the extent of vulnerability is obviously equal on the entire area of the Hajdúhát loess territory, but according to Figure 1 its northern and southern parts were classified into different groups. Reports based on natural landscape borders have also been created, but these apply to landscape scenery protection (Fig. 2). 


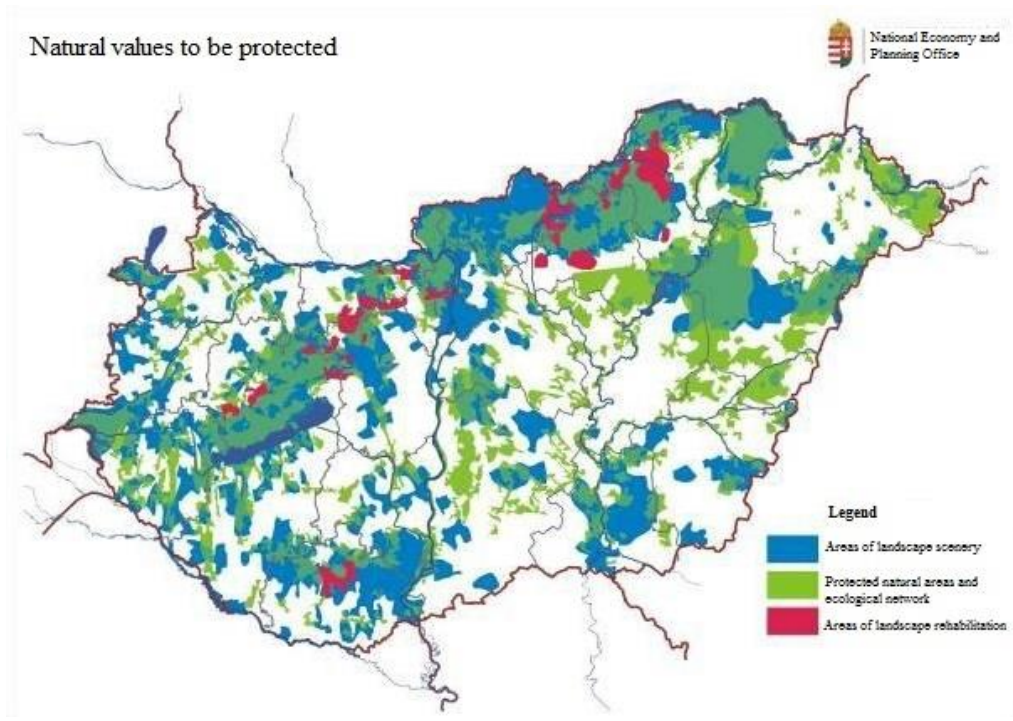

Source: National Development 2020 [10]

Figure 2. Natural values to be protected

The contents of Figure 1 are also hard to reconcile with the map applying the conservation of natural values published in NF2020 (Fig. 3).

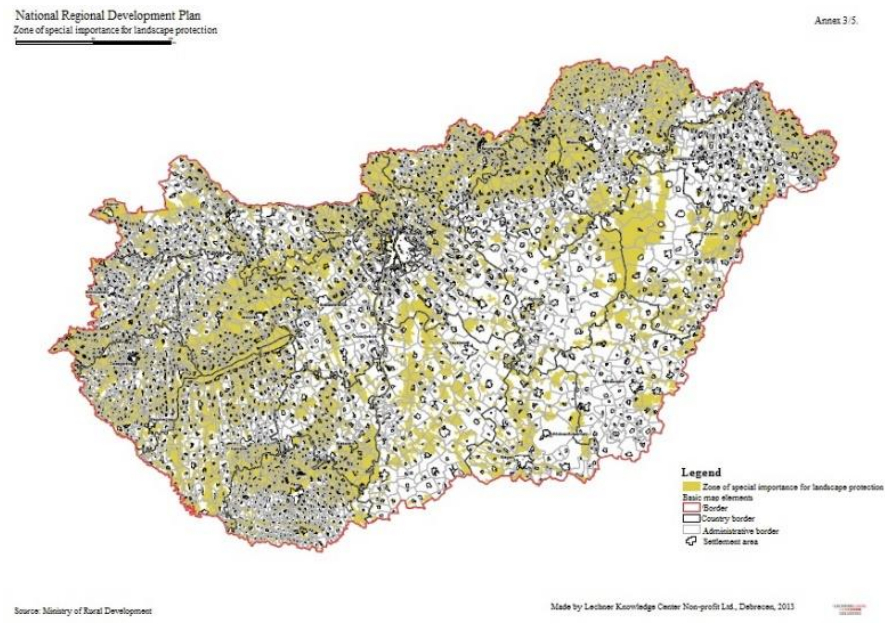

Source: National Regional Development Plan 2013 [22]

Figure 3. Zone of special importance for landscape protection 
Furthermore, NF2020 states that the most vulnerable region is the part of the country situated south from the Nagykanizsa-Budapest-Tokaj line, which is in contradiction with the information presented in Figure 1. According to Figure 1 , the least vulnerable areas can be found in this county.

\section{E. The role of vegetation coverage}

Beyond the predominant continental effects, the weather of the country is also affected by oceanic and Mediterranean impacts. For the most part, this climatic transition zone is the cause of the mosaic nature of soils, precipitation patterns, and natural vegetation coverage. The biogeographic zonality characteristic of Eastern Europe ends in the Carpathian Basin, where it gradually changes to the speckled pattern which can be seen in the western part of the continent. It results in a great variability, which is one of the major natural geographical characteristics of the Carpathian Basin and the reason why the Pannonian Biogeographical Region is recognized as a separate type. Now, when global climate changes pose a significant risk to the existence of several natural habitats, the mosaic characteristic is a beneficial property because the different degree of climate vulnerability of each habitat type allows the gradual transformation of the regional pattern (NTS).

The NTS explains in detail that the changes in urban lifestyle habits as well as the accompanying changes and needs lead to an ever denser infrastructure network, the decrease of biodiversity, and the fragmentation of natural habitats. The need for larger living spaces, the increase in the number of services, and the use of cars all contributed to the development of city peripherals, increased fragmentation, and the change of landscape features. Based on the data of the Hungarian Central Statistics Office, urban areas made up 22\% of the area of the country in the period of 2013-2014, which is comparable to the combined ratio of Natura 2000 and forest areas.

With regard to the mitigation of the negative consequences of climate change, forest coverage plays a key role since it absorbs $12-15 \%$ of the carbon emission, among others. The forest coverage ratio of Hungary $(21 \%)$ is lower than the EU average, even though according to the National Development 2020 as well as the National Development 2030 the extent of forest areas is constantly increasing. According to the National Landscape Strategy, the forest coverage of Hajdú-Bihar County (with the exception of its northeastern part) is lower than $10 \%$, the increase of which is neither expected nor necessary considering Hortobágy and the exceptional land properties of Hajdúhát. The nature conservation priorities in connection with the Hortobágy National Park can only partly apply to forest areas [21]. Forestation and green area management in the county should be focused on urban environments because these are the areas 
where direct life conditions can be improved most significantly. This special situation of the county is not detailed either in NF2020 or in NF2030. Forestation is considered a general method for improvement even though it is obvious that the forestation ratio of the county is low now and will stay low in the future.

\section{F. Landscape strategy}

As opposed to other strategies and concepts, the NTS includes specific goals and tasks in connection with the government, the local government, NGOs, and research organizations. A compilation of the landscape reports and documents specifying landscapes is required by the European Commission. The NTS meets this requirement by stating that its comprehensive goal is responsible landscape use based on landscape properties, and in order to reach these goals it also contains horizontal principles such as the protection of natural resources and cultural heritage, economical land use, and adaptation to climate change. One of its priorities is the enhancement of landscape identity, social participation and its integration into education. Further objectives include the improvement of data of records, complex landscape research, reassessment of land use, the climatefriendly development of settlement models that take value conservation into account, the reassessment of the National Curriculum for Basic Education, and the organization of training programmes. The fact that a complex landscape evaluation method which would appropriately reflect the interests of sectors from forest management to tourism is still under development makes it more difficult to implement the goals of the landscape strategy.

\section{G. The financial framework of developments}

The most significant support for the implementation of developments comes from the European Union in connection with the operative programmes (EEOP, CCOP, EDIOP, HFOP). According to the 2020 and the 2030 concepts, the current financial framework applies to the periods of 2007-2013 and 2007-2014 respectively. This difference is important because the amount of the support is 24.9 billion euros, and it matters exactly how many years it is available for. It is not reassuring either that, e.g., the Hajdú-Bihar County climate strategy created in February 2018 hardly mentions the financial aspects of the implementation. 


\section{Conclusions}

As we could see above, many ambitious strategies have been created to facilitate changes. However, in many cases, there are significant differences between the contents of the National Development 2020, 2030, and other strategies. We find that the data applying to the same year differ in the two development plans, or they are simply not in accordance with the landscape strategy and the climate change strategies. Among the projects supported by the European Union, the most important are the Hajdú-Bihar County climate strategy accepted in February 2018 and the still ongoing national programme with the identification number KEHOP-4.3.0-15-2016-00001 (strategic assessments supporting the long-term conservation of natural values of community interest as well as the national implementation of the EU Biodiversity Strategy for 2020), which can facilitate the further involvement of the society, and thereby we can make a step towards the solution of a very complex natural problem.

In the case of Hungarian strategies, it would be important to demonstrate how well they correspond with the plans of the European Union and to what extent they meet the requirements of the EU. The changing objectives of the European Union make it difficult to develop mutually supportive strategies. These strategies can only fulfil their purpose if the real motivations behind their creation are the battle against climate change and the need for development. It is, of course, a very delicate subject to discuss these guidelines in a region which is lagging behind, where the current commitments are not in accordance with the EU objectives.

\section{References}

[1] Bánóczki, Krisztina (2018), Az aktuális környezetvédelmi, éghajlatváltozási, táj- és területfejlesztési stratégiák Debrecenre vonatkozó részeinek összehasonlító elemzése. In: Lázár I. (ed.), Környezet és energia. 229-234.

[2] Bánóczki, Krisztina (2018), Az érvényes éghajlatváltozási, táj- és területfejlesztési stratégiák Hajdú-Bihar megyére vonatkozó részeinek összehasonlító elemzése. Debreceni Szemle 2018/3, 289-299.

[3] Gyulai, Iván (2013), Fenntartható fejlödés és fenntartható növekedés. Statisztikai Szemle 91(8-9), 797-822.

[4] IPCC. (2014), Climate Change 2014: Synthesis report. Contribution of Working Groups I, II and III to the Fifth Assessment Report of the Intergovernmental Panel on Climate Change [core writing team: R. K. Pachauri, L. A. Meyer (eds.)]. IPCC, Geneva, Switzerland. 1-31. (https://www.met.hu/eghajlat/eghajlatvaltozas/IPCC_jelentes/index.php?id=2260\&hir=IPC C_5._ertekelo_jelentes_donteshozoi_osszefoglaloja (downloaded on: 05.02.2019).

[5] http://www.biodiv.hu/convention/F1117799202_(accessed on: 05.02.2019).

[6] http://www.unis.unvienna.org/unis/hu/thematic_info_climate_change_unfccc.html (accessed on: 05.02.2019). 
[7] http://www.unesco.hu/termeszettudomany/fenntarthato-fejlodesre/fenntarthato-fejlodes (accessed on: 05.02.2019).

[8] http://mek.oszk.hu/10900/10978/10978.pdf (accessed on: 05.02.2019).

[9] http://unipub.lib.uni-corvinus.hu/710/1/AH_2006_NSGY.pdf (accessed on: 05.02.2019).

[10] Nemzeti Fejlesztés 2020 [National Development Concept 2020] (www.kormanyhivatal.hu). (downloaded on: 05.09.2017).

[11] Nemzeti Fejlesztés 2030 [National Development Concept 2030] - Országos Fejlesztési és Területfejlesztési Koncepció (www.kormanyhivatal.hu). (downloaded on: 03.11.2017).

[12] Nemzeti Éghajlatváltozási Stratégia 2008-2025 [First National Climate Change Strategy 20082025] (http://nakfo.mbfsz.gov.hu//sites/default/files/files/nes080214.pdf). (downloaded on: 05.09.2017).

[13] Második Nemzeti Éghajlatváltozási Stratégia 2014-2025 [Second National Climate Change Strategy 2014-2025]

(http://www.kormany.hu/download/f/6a/f0000/N\%C3\%89S_2_strat\%C3\%A9gia_2017_02 27.pdf). (downloaded on: 05.09.2017).

[14] Nemzeti Tájstratégia 2017-2025 [National Landscape Strategy 2017-2025] (http://www.kormany.hu/download/c/ff/f0000/Nemzeti\%20T\%C3\%A1jstrat\%C3\%A9gia_ 2017-2026.pdf) (downloaded on: 17.11.2017).

[15] Hajdú-Bihar megyei Területfejlesztési Program Stratégiai Programrész 2014 [Strategic Development Programme of Hajdú-Bihar County]

(https://www.hbmo.hu/webdocs/Files/Portal/HB_Strategiai_Program.pdf) (downloaded on: 17.11.2017).

[16] Debrecen MJV Településfejlesztési Koncepciója és Integrált Településfejlesztési Stratégiája 2014-2020 [Debrecen MJV Urban Development Concept and Integrated Urban

Development Strategy 2014-2020] (https://www.debrecen.hu/assets/media/file/hu/7309/ koncepcio.pdf) (accessed on: 17.11.2017).

[17] KSH Statisztikai Tükör (accessed on: 30.04.2018).

[18] Tájékoztató az új Megújuló Energia Támogatási Rendszerröl (METÁR) (http://www.mekh.hu/download/1/7b/20000/mekh_metar_tajekoztato_2017jan.pdf). (accessed on: 13.01.2018).

[19] http://www.ovf.hu/hu/futo-projektek/66d751f7-6e9f-4717-96da-78d04e791bba. (accessed on: 08.05.2018).

[20] http://www.haon.hu/egyedulallo-mesterkepzes-a-de-n/3676188 (accessed on: 14.11.2017).

[21] http://www.termeszetvedelem.hu/termeszetvedelmi-celkituzesek-prioritasok-natura-2000teruleteken (accessed on: 13.10.2017).

[22] Országos Területrendezési Terv 2013 [National Regional Development Plan 2013] http://www.terport.hu/teruletrendezes/teruletrendezesi-tervek/magyarorszag (accessed on: 03.11.2017).

[23] Fazekas, I. et al. (2013), Biogas utilization and its environmental benefits in Hungary. International Review of Applied Sciences and Engineering 4(2), 129-136.

[24] Szabó, Gy., Fazekas, I., Kisari, K., Buday, T., Szabó, G., Szabó, Sz., Paládi, M., Kerényi, A. (2014), The environmental and economic aspects of a biogas power plant. WIT Transactions on Ecology and the Environment 186, 149-160.

[25] Szabó, Gy., Fazekas, I., Szabó, Sz., Szabó, G., Buday, T., Paládi, M., Kisari, K., Kerényi, A. (2014), The carbon footprint of a biogas power plant. Environmental Engineering and Management Journal 13(11), 2867-2874. 